\title{
Master of Law
}

National Cancer Institute

\section{Source}

National Cancer Institute. Master of Law. NCI Thesaurus. Code C71363.

An advanced law degree generally earned in a course of specialized study in law. 